\title{
Stakeholder Perceptions of an Ecosystem Services Approach to Clearing Invasive Alien Plants on Private Land
}

\author{
Lauren S. Urgenson $^{1}$, Heidi E. Prozesky ${ }^{2,3}$ and Karen J. Esler ${ }^{3,4}$
}

\begin{abstract}
Incentivizing private landowners and other stakeholders is central to the effective conservation of ecosystem services in working landscapes. To better understand how to design effective incentives, the perceptions of landowners and other stakeholders are explored regarding a proposed approach to clearing invasive alien plants on private land in the Western Cape Province, South Africa. The public funded national program, Working for Water, conserves ecosystem services while employing and training people from marginalized sectors of society to clear these plants. Private landowner involvement is a key conservation challenge, because without adequate landowner involvement, invasive alien plants persist on the landscape and continuously reinvade cleared areas. We collected interview data from private landowners in three study sites, and websurvey data from conservation professionals and Working for Water managers, in order to compare stakeholder perceptions of (1) government and landowners' responsibilities for clearing invasive alien plants; (2) existing and proposed policy tools; and (3) the extent to which stakeholders consider the proposed financial incentive to be sufficient. There was significant consensus among stakeholders concerning their preference for shared landowner and government responsibility and for a policy mix that combines incentives with disincentives. Landowners from the three study sites differed in the level of responsibility they were willing to assume. Stakeholders also diverged in terms of their perceptions of the proposed financial incentives. Furthermore, the perspectives of landowners were strongly associated with ecological and social features of the landscapes in which they are located. Understanding stakeholders' points of view within their differing contexts is shown to be a valuable means of gaining insight into the opportunities and constraints that face ecosystem service conservation in working landscapes.
\end{abstract}

Key Words: ecosystem services; invasive alien plants; landowner incentives; private land; stakeholder analysis; Western Cape; Working for Water; working landscapes

\section{INTRODUCTION}

Ecosystem services (ESs) are the material and nonmaterial benefits humans derive from nature (Millennium Ecosystem Assessment 2005). Resource management initiatives worldwide have embraced ES concepts as a means to align ecological conservation with socioeconomic decisions related to the environment (Daily et al. 2009). ES approaches are based on a recognition that conservation targets cannot be achieved in formal protected areas alone, thus there is a need to integrate conservation into the routine activities taking place on private lands, i.e., on production (e.g., agricultural) and nonproduction (e.g., residential) lands. Landowners may lack incentives to safeguard ESs and as such, ES approaches often require the design of novel institutions (North 1990, Ostrom 1990) to enhance service delivery. Examples of institutional arrangements for ESs include financial incentives, legal regulations, and motivational tools (i.e., extension services, education, and information) (Young et al. 1996, Botha 2001).

Designing institutions to fit the social, economic, and ecological context of the systems they aim to protect presents a core ES policy and management challenge (Folke et al. 2007, Jack et al. 2008). Often the scale of ES management extends over several property boundaries, which requires broad-based stakeholder cooperation (Goldman et al. 2007, Cowling et al. 2008). Stakeholders may hold varying perspectives on ES values, approaches, and outcomes (Turner 2008). Furthermore, many ESs by their nature constitute public benefits (e.g., water availability, biodiversity), and institutions for promoting effective ES delivery often need to address the property rights, responsibilities, and economic self-interests of private landowners (Hanna et al. 1997, Goldman et al. 2007).

Engagement with key stakeholders at the outset is critical for the design of effective ES institutions and, ultimately, the successful uptake of ES initiatives (Grimble and Wellard 1997, Wondolleck and Yaffee 2000, Cowling et al. 2008, Reed 2008). Until recently, literature on ESs has focused on biophysical and economic valuation aspects, rather than dealing explicitly with stakeholder values and perceptions (Menzel and Teng 2010). There is a pressing need to examine stakeholder perspectives of ES initiatives in order to guide the design of policy instruments that are consistent with a particular ecological, social, and economic situation, and with the capabilities of institutions and stakeholders (Cocklin et al. 2007). Although many of these conditions are likely to be location specific (Wandel and Smithers 2000, Siebert et al.

\footnotetext{
${ }^{1}$ School of Environmental and Forest Sciences, College of the Environment, University of Washington, ${ }^{2}$ Department of Sociology and Social Anthropology, Stellenbosch University, South Africa, ${ }^{3}$ DST-NRF Centre of Excellence for Invasion Biology, Stellenbosch University, South Africa, ${ }^{4}$ Department of Conservation Ecology and Entomology, Stellenbosch University, South Africa
} 
Table 1. Summary of Working for Water's (WfW) proposed approach to clear invasive alien plants (IAPs) on private land in the Western Cape, South Africa.

\begin{tabular}{|c|c|c|}
\hline Policy Tool & Proposed Action & Action Goals \\
\hline \multicolumn{3}{|l|}{ Incentives } \\
\hline Financial assistance & $\begin{array}{l}\text { WfW provides } 100 \% \text { of the labor costs for the } \\
\text { initial clearing, } 75 \% \text { of the labor costs for the first } \\
\text { follow-up clearing, } 50 \% \text { of the labor costs for the } \\
\text { second follow-up clearing, and } 100 \% \text { of the } \\
\text { herbicide costs for the initial clearing and three } \\
\text { follow-up clearings. }\end{array}$ & $\begin{array}{l}\text { Overcome barriers in landowners' financial } \\
\text { capacity to clear IAPs. Facilitate greater sharing } \\
\text { between WfW and private landowners of the costs } \\
\text { for clearing IAPs. }\end{array}$ \\
\hline Extension services & $\begin{array}{l}\text { WfW provides expert advice on clearing methods, } \\
\text { training, and management support. }\end{array}$ & $\begin{array}{l}\text { Provide landowners with guidance, assistance, and } \\
\text { motivation to bring IAPs under control. }\end{array}$ \\
\hline \multicolumn{3}{|l|}{ Disincentives } \\
\hline National regulations & $\begin{array}{l}\text { Enforcement of national mandates (CARA } \dagger \text { and } \\
\text { NEMBA } \$ \text { ) that hold landowners accountable for } \\
\text { clearing IAPs on their land. }\end{array}$ & $\begin{array}{l}\text { Reinforce landowner motivation to clear IAPs on } \\
\text { their property. }\end{array}$ \\
\hline Landowner contracts & $\begin{array}{l}\text { Enforcement of legally binding agreements } \\
\text { between WfW and landowners. Landowners agree } \\
\text { to pay the remaining portion of the clearing costs } \\
\text { during the subsidy period, and to maintain the } \\
\text { subsequent follow-up work. }\end{array}$ & $\begin{array}{l}\text { Compel landowner accountability for the control of } \\
\text { IAPs on their property and facilitate long-term } \\
\text { sustainability in the control of the IAPs. }\end{array}$ \\
\hline
\end{tabular}

2006, Winter et al. 2007), several ecological and social factors, including organizational affiliation (Prell et al. 2010), economic dependence on property (Moon and Cocklin 2011), nature or stewardship ethic (Kabii and Horwitz 2006), familiarity with the management practice (Schirmer et al. 2012) and communication and information networks (Siebert et al. 2006), have been demonstrated to be influential in the conservation perceptions and policy preferences of stakeholders. Studies designed to highlight variation in perceptions and preferences for ES conservation across stakeholder groups and geographical areas that encompass variation in these factors are rare, however.

We investigate the perceptions of diverse stakeholders regarding an ES scheme to clear invasive alien plants (IAPs) on private land in the Western Cape, South Africa. Working for Water (WfW) is a government initiative established in 1995 to sustainably control IAPs "in order to contribute to economic empowerment, social equity and ecological integrity" in South Africa (Department of Water Affairs and Forestry 2007:2). WfW employs and trains people from marginalized sectors of society to clear IAPs from waterways and other ecologically sensitive habitats. IAPs displace native species, result in dramatic water losses (Van Wilgen et al. 1998, Le Maitre et al. 2000, Marais and Wannenburgh 2008), and increase fire intensity and frequency as well as soil erosion in invaded areas, thereby affecting ESs (Van Wilgen 2009). Private landowners' participation is an important challenge for WfW to address (Woodworth 2006, Guy Preston, personal communication), because the majority of land in South Africa is privately owned. Without landowner support, IAPs persist on the landscape and continuously reinvade cleared areas.

In 2008, WfW proposed a new combination of incentives and disincentives to promote landowner clearing of IAPs, entitled, "Approach to Work on Private Land" (Table 1; http://www. dwaf.gov.za/wfw/control). Outcomes of this new approach are highly dependent on the extent to which the proposed incentives align with stakeholders' perceptions, values, and needs, so as to influence their behavior. Currently, the diversity of stakeholder orientations toward IAPs and their management are not well understood (G. Preston, personal communication).

Our objective is to describe and contextualize the perceptions of private landowners, conservation professionals, and managers within WfW regarding key aspects of WfW's proposed Approach to Work on Private Land. We compared perceptions of these key stakeholder groups, and perceptions of landowners across three study sites, regarding: (1) government and landowners' responsibilities for clearing IAP; (2) the use of existing and proposed policy tools, including legal mandates, financial assistance, and extension services, as incentives for landowners to clear IAPs; and (3) the extent to which the quantity and duration of WfW's proposed financial assistance are considered sufficient to offset landowners' costs for clearing IAPs on their property. 
Table 2. Characteristics of landowner study sites, Western Cape ( $\mathrm{n}=$ number of respondents at each site).

\begin{tabular}{|c|c|c|c|}
\hline Variable & Wilderness $(n=41)$ & Grabouw $(n=37)$ & Citrusdal $(n=35)$ \\
\hline Latitude and longitude & $33^{\circ} 59^{\prime} 32^{\prime \prime} \mathrm{S}, 22^{\circ} 35^{\prime} 0^{\prime \prime} \mathrm{E}$ & $34^{\circ} 9^{\prime} 15^{\prime \prime} \mathrm{S}, 19^{\circ} 00^{\prime} 46^{\prime \prime} \mathrm{E}$ & $32^{\circ} 35^{\prime} 29.94^{\prime \prime} \mathrm{S}, 19^{\circ} 00^{\prime} 45^{\prime \prime} \mathrm{E}$ \\
\hline Climate $\dagger$ & Maritime & Mediterranean - high rainfall & Mediterranean - semi-arid \\
\hline Mean annual precipitation (mm) & $>1200$ & $<600$ & $<300$ \\
\hline Mean monthly maximum temperature $\left({ }^{\circ} \mathrm{C}\right)$ & 28 in February & 29 in February & 22 in February \\
\hline Mean monthly minimum temperature $\left({ }^{\circ} \mathrm{C}\right)$ & 14 in July & 7 in February & 10 in July \\
\hline Mean property size (ha) & 6 & 300 & 1700 \\
\hline Primary land use & $\begin{array}{l}\text { Residential private property } \\
\text { highly interspersed with public } \\
\text { parklands }\end{array}$ & $\begin{array}{l}\text { Agricultural and lifestyle private } \\
\text { property moderately interspersed } \\
\text { with public parkland }\end{array}$ & $\begin{array}{l}\text { Agricultural private property not } \\
\text { interspersed with public parklands }\end{array}$ \\
\hline Primary agricultural products & N/A & Apples and grapes & Citrus fruit and rooibos \\
\hline $\begin{array}{l}\text { Previous experience working with WFW } \\
\text { (\% of interviewees) }\end{array}$ & Low $(22 \%)$ & Medium (30\%) & $\operatorname{High}(66 \%)$ \\
\hline IAP distribution & $\begin{array}{l}\text { Dispersed across waterways and } \\
\text { upland areas }\end{array}$ & $\begin{array}{l}\text { Dispersed across waterways and } \\
\text { upland areas }\end{array}$ & Concentrated along waterways \\
\hline
\end{tabular}

$\dagger$ Climate data are from world weather on-line (www.worldweatheronline.com).

\section{METHODS}

\section{Study area}

The Western Cape Province occupies $129,386 \mathrm{~km}^{2}$ at the southern tip of Africa, and lies within the Cape Floristic Region (CFR): a biodiversity and ES hotspot globally recognized for its exceptional endemic flora (Cowling and Richardson 1995) and as a source of a substantial portion of South Africa's surface water supply (Turpie et al. 2008). Most land is privately owned, with less than $3 \%$ located in protected areas (Rebelo and Siegfried 1992), and agriculture is a primary industry (Orkin 1998).

Invasion by alien plants, particularly trees and large shrub species, poses a significant threat to the indigenous flora, water resources, and other ESs in the Western Cape (Van Wyk 1987, Le Maitre et al. 1996, Van Wilgen 2009). Dominant IAPs include wattles (Acacia and Paraserianthes spp.), blue gums (Eucalyptus spp.), hakeas (Hakea spp.) and pines (Pinus spp.). Control of these IAPs can prove challenging due to their rapid growth rates, copious seed production, wide dispersal distances, large and long-lived soil seed banks, and adaptations to fire, in particular post-fire flushes of IAP seedlings (Marais and Wannenburgh 2008, Van Wilgen 2009). Previously cleared areas can revert to heavily invaded areas if funds or capacity do not allow for prompt postfire follow-up (Holmes et al. 2008, Pretorius et al. 2008).

IAPs in the Western Cape have a long history (Witt 2003, Van Wilgen 2009). Early in the $19^{\text {th }}$ century, the State embarked on extensive alien tree growing campaigns to render South Africa independent of international wood and timber markets. Landowners were encouraged to cultivate alien trees through incentives and tree growing competitions. By the 1960s a subset of alien species was recognized as problematic, and widespread campaigns to remove IAPs were initiated in the 1980s. The 1983 Conservation of Agricultural Resource Act (Act 43 of 1983, amended in 2001) and the 2004 National
Environmental Management Biodiversity Act (Act 10 of 2004) place restrictions on the growth, propagation, and trade of designated IAP species on public and private land.

\section{Sample selection}

Landowner study sites and landowners

We purposively selected three landowner study sites to represent variation in biophysical and land use contexts that have been demonstrated to influence landowner perceptions and management of ecosystem services in the Western Cape (Winter et al. 2007, Roura-Pascual et al. 2009) and elsewhere (Curtis and Robertson 2003, Moon and Cocklin 2011). Thus, our findings potentially have a broader relevance to settings beyond the scope of this study. These study sites were also identified by WfW as potential pilot project areas for their new Approach to Work on Private Land. Profiles of the landowner research sites are provided in Table 2.

The landowner stakeholder group includes property owners or land managers with primary decision making authority on the property. For each study site, we obtained a comprehensive list of landowners from a local land management agency. After excluding landowners with properties sizes $\leq 1$ ha, we randomly selected potential respondents from this list, who were then requested by telephone to participate in an interview. Response rates of $88 \%, 78 \%$, and $94 \%$ were attained in Wilderness, Grabouw, and Citrusdal, respectively. The realized sample consisted of 113 landowners, divided more or less equally across the three study sites (41 in Wilderness, 37 in Grabouw and 35 in Citrusdal).

\section{Conservation professionals}

The conservation professional stakeholder group includes provincial government and NGO land managers, researchers, and policy makers with experience working on the management of IAPs on private land. Respondents were initially identified by WfW management. Subsequent 
Table 3. Variables used in analysis of stakeholder perceptions regarding WfW's proposed ecosystem service (ES) approach to clearing IAPs on private land, Western Cape.

\begin{tabular}{|c|c|}
\hline Variable & Attributes \\
\hline \multicolumn{2}{|l|}{ Respondent category } \\
\hline Stakeholder group & Categorical; landowner, conservation professional, WfW manager \\
\hline Landowner study site & Categorical; Wilderness, Grabouw, Citrusdal \\
\hline \multicolumn{2}{|l|}{ Closed-ended questionnaire item } \\
\hline Extent to which responsibility should be shared & Categorical; shared, unshared, unsure \\
\hline Level of responsibility & $\begin{array}{l}\text { Categorical; solely or primarily landowner, equal landowner and government, solely or } \\
\text { primarily government }\end{array}$ \\
\hline Level of support for regulatory enforcement & Categorical; agree, disagree, unsure \\
\hline Level of support for motivational incentives & Categorical; agree, disagree, unsure \\
\hline Level of support for monetary incentives & Categorical; agree, disagree, unsure \\
\hline Opinion on sufficiency of subsidy quantity & Categorical; fully sufficient, somewhat sufficient, not at all sufficient, unsure \\
\hline Opinion on sufficiency of subsidy duration & Categorical; fully sufficient, somewhat sufficient, not at all sufficient, unsure \\
\hline \multicolumn{2}{|l|}{ Open-ended questionnaire item } \\
\hline Emergent themes - responsibility & Dummy; $1=$ present, $0=$ absent \\
\hline Emergent themes - financial structure & Dummy; $1=$ present, $0=$ absent \\
\hline
\end{tabular}

respondents were selected based on peer recommendation, using a snowball sampling technique (Biernacki and Waldorf 1981) until no new respondents were suggested. In total, 47 conservation professionals were invited via e-mail to complete an online questionnaire, and a $55 \%$ response rate $(26$ responses) was achieved.

\section{WfW managers}

All WfW managers in the Western Cape were invited via email and telephone to complete an online questionnaire. The questionnaire was sent to 32 managers, and we received 18 responses (a 56\% response rate). Citing limited computer access and time, two questionnaires were submitted by managers as joint responses. Therefore, the 18 cases reflect the perspectives of a slightly larger number of WfW managers.

\section{Data collection}

Our data were obtained in 2009 from face to face, semistructured interviews with private landowners, and online questionnaires (administered with Checkbox 4.6 online survey software at http://www.checkbox.com) completed by local conservation professionals and WfW managers.

Data collection tools included a combination of closed- and open-ended questions. The former allowed the quantitative measurement of key constructs, while the latter allowed stakeholders' perceptions to emerge without preempting, and provided qualitative data (Tashakkori and Teddlie 2003, Creswell 2009). Participation was voluntary; informed consent was obtained and confidentiality assurances given to all respondents.

The data collection tools were reviewed by WfW management and experts in several conservation organizations. We also piloted the landowner interview schedule with three respondents not included in the sample, to ensure the questionnaire items were appropriate for the Western Cape context.

\section{Analyses}

We used a concurrent mixed methods analytic approach (Tashakkori and Teddlie 2003, Creswell 2009), combining qualitative and statistical methods to examine the relationship between perceptions of the policy principles and the financial structure of WfW's proposed approach (dependent variables) and the following two independent variables: (1) stakeholder group (all respondents), and (2) study site (landowners only) (Table 3).

With regard to (1), we tested for associations between stakeholder group and participants' responses to seven closedended questionnaire items using chi-square analysis $(P \leq$ 0.05 ). We conducted the analysis of (2) in several stages. First, as with (1), we tested for associations between landowner study site and participants' responses to closed-ended questionnaire items using chi-square analysis $(\mathrm{p} \leq 0.05)$. Next, we used thematic coding and a grounded theory approach to identify emergent themes in landowner responses to openended questions. These were subsequently numerically translated into dichotomous variables ( 0 or 1$)$, corresponding to the absence or presence, respectively, of a theme in an interview transcript. Such quantification enabled us to examine associations between the themes, landowner study site, and responses to closed-ended items.

Finally, we used Dufrêne-Legendre indicator value (IV) analysis (Dufrêne and Legendre 1997, Bakker 2008) to test for associations between emergent themes and study site or landowner responses to closed-ended items. In the latter case, we ran a blocked indicator value analysis and accounted for 
Table 4. Relationships between stakeholder group and participant responses to closed-ended questionnaire items regarding the principles and structure of WfW's proposed ecosystem service approach to clearing IAPs on private land, Western Cape. Values are the frequency observed (expected) based on chi-square tests.

\begin{tabular}{|c|c|c|c|c|c|}
\hline \multirow[b]{2}{*}{ Variable } & \multicolumn{3}{|c|}{ Stakeholder Group } & \multirow[b]{2}{*}{$X^{2}$} & \multirow[b]{2}{*}{$p$} \\
\hline & Landowners & Conservation Professionals & WfW Managers & & \\
\hline Shared responsibility $(\mathrm{n}=156)$ & & & & 19.9 & .001 \\
\hline shared & $107(104)$ & $18(23)$ & $18(17)$ & & \\
\hline unshared & $5(6)$ & $3(1)$ & $0(1)$ & & \\
\hline unsure & $1(4)$ & $4(1)$ & $0(1)$ & & \\
\hline Responsibility category $(\mathrm{n}=131)$ & & & & 1.04 & 0.79 \\
\hline solely or primarily landowner & $63(61)$ & -- & $8(10)$ & & \\
\hline equal landowner and government & $30(31)$ & -- & $6(5)$ & & \\
\hline solely or primarily government & $19(20)$ & -- & $4(3)$ & & \\
\hline Regulatory enforcement $(\mathrm{n}=155)$ & & & & 9.50 & 0.05 \\
\hline agree & $73(80)$ & $20(18)$ & $17(13)$ & & \\
\hline disagree & $34(28)$ & $3(6)$ & $1(4)$ & & \\
\hline unsure & $5(5)$ & $2(1)$ & $0(1)$ & & \\
\hline Motivational incentives $(\mathrm{n}=154)$ & & & & 1.24 & 0.87 \\
\hline agree & $105(106)$ & $24(24)$ & $18(17)$ & & \\
\hline disagree & $5(4)$ & $1(1)$ & $0(1)$ & & \\
\hline unsure & $1(1)$ & $0(0)$ & $0(1)$ & & \\
\hline Monetary incentives $(\mathrm{n}=154)$ & & & & 23.5 & $<0.001$ \\
\hline agree & $102(96)$ & $22(22)$ & $9(16)$ & & \\
\hline disagree & $8(14)$ & $3(3)$ & $8(2)$ & & \\
\hline unsure & $1(1)$ & $0(0)$ & $1(0)$ & & \\
\hline Quantity of proposed financial incentive $(n=150)$ & & & & 31.1 & $<0.001$ \\
\hline fully sufficient & $41(31)$ & $0(7)$ & $1(4)$ & & \\
\hline somewhat sufficient & $41(48)$ & $17(11)$ & $6(6)$ & & \\
\hline not at all sufficient & $26(24)$ & $2(5)$ & $4(3)$ & & \\
\hline unsure & $4(9)$ & $6(2)$ & $2(1)$ & & \\
\hline Duration of proposed financial incentive $(n=150)$ & & & & 35.4 & $<0.001$ \\
\hline fully sufficient & $40(31)$ & $1(7)$ & $0(4)$ & & \\
\hline somewhat sufficient & $36(48)$ & $20(11)$ & $8(6)$ & & \\
\hline not at all sufficient & $29(23)$ & $0(5)$ & $2(3)$ & & \\
\hline unsure & $7(11)$ & $4(2)$ & $3(1)$ & & \\
\hline
\end{tabular}

landowner study site as a blocking factor. Statistical significance of IVs was determined via Monte Carlo randomizations (5000 permutations).

We conducted chi-squared tests with IBM SPSS Statistics version 18, and indicator value analysis in PC-ORD 6.0. Transcriptions of landowner interviews were analyzed with the aid of ATLAS.ti version 6.1.1.

\section{RESULTS}

\section{Government and landowner responsibility}

By far the largest majority (92\%) of all stakeholders believed responsibility for clearing IAPs on private land should be shared among government and landowners ( $p=0.001$; Table 4). Although landowners were generally positive toward the notion of shared responsibility for IAP clearing efforts, variation existed in terms of the level of responsibility they were willing to assume. More than half $(53 \%)$ believed responsibility for clearing IAPs should be solely or primarily the landowners', 27\% believed it should be shared equally between them and the government, and $15 \%$ considered it solely or primarily the government's responsibility (Table 5).
There were no significant differences in perceptions among stakeholder groups regarding the level of landowner and government responsibility $(\mathrm{p}=0.79)$.

Qualitative analysis of landowner interview transcripts produced emergent themes associated with government and landowner responsibility for clearing IAPs (Table 6). Indicator analysis showed strong associations between four emergent themes and landowners' responses to the closed-ended question about responsibility (Table 7). Two themes, "landowners have a duty to steward property" and "landowners can clear at a lower overall cost", were associated with landowners who perceive they should hold sole or primary responsibility for clearing IAPs $(\mathrm{P}<0.01,52$ and $22 \%$, respectively; $\mathrm{n}=63$ ). The theme "government coordination is needed" was marginally associated with landowners who perceive equal responsibility between themselves and the government $(\mathrm{P}=0.056,43 \%, \mathrm{n}=30)$. The theme "the state's historic role in IAP introduction and spread" was associated with landowners who perceive the government should take sole or primary responsibility for clearing IAPs $(\mathrm{P}<0.01,58 \%, \mathrm{n}=19)$. 
Table 5. Relationships between landowner study site and participant responses to closed-ended questionnaire items regarding the principles and structure of WfW's proposed ecosystem service approach to clearing IAPs on private land, Western Cape. Values are the frequency observed (expected) based on chi-square tests.

\begin{tabular}{|c|c|c|c|c|c|}
\hline \multirow[b]{2}{*}{ Variable } & \multicolumn{3}{|c|}{ Landowner Study Site } & \multirow[b]{2}{*}{$X^{2}$} & \multirow[b]{2}{*}{$p$} \\
\hline & Wilderness & Grabouw & Citrusdal & & \\
\hline Shared responsibility $(\mathrm{n}=113)$ & & & & 4.67 & 0.32 \\
\hline shared & $38(39)$ & $35(35)$ & $34(33)$ & & \\
\hline unshared & $3(2)$ & $2(2)$ & $0(2)$ & & \\
\hline unsure & $0(0)$ & $0(0)$ & $1(0)$ & & \\
\hline Responsibility category $(\mathrm{n}=112)$ & & & & 8.89 & 0.064 \\
\hline solely or primarily landowner & $28(23)$ & $22(21)$ & $13(19)$ & & \\
\hline equal landowner and government & $8(11)$ & $11(10)$ & $11(9)$ & & \\
\hline solely or primarily government & $5(7)$ & $4(6)$ & $10(6)$ & & \\
\hline Regulatory enforcement $(n=112)$ & & & & 6.99 & 0.14 \\
\hline agree & $32(26)$ & $23(24)$ & $18(23)$ & & \\
\hline disagree & $7(12)$ & $12(11)$ & $15(11)$ & & \\
\hline unsure & $1(2)$ & $2(2)$ & $2(2)$ & & \\
\hline Motivational incentives $(\mathrm{n}=111)$ & & & & 0.831 & 0.081 \\
\hline agree & $39(38)$ & $36(34)$ & $30(33)$ & & \\
\hline disagree & $1(2)$ & $0(2)$ & $4(2)$ & & \\
\hline unsure & $0(0)$ & $0(0)$ & $1(0)$ & & \\
\hline Monetary incentives $(\mathrm{n}=111)$ & & & & 2.68 & 0.61 \\
\hline agree & $38(37)$ & $33(33)$ & $31(32)$ & & \\
\hline disagree & $2(3)$ & $3(3)$ & $3(3)$ & & \\
\hline unsure & $0(0)$ & $0(0)$ & $1(0)$ & & \\
\hline Quantity of proposed financial incentive $(n=112)$ & & & & 15.0 & 0.02 \\
\hline fully sufficient & $13(15)$ & $18(14)$ & $10(13)$ & & \\
\hline somewhat sufficient & $13(15)$ & $17(14)$ & $11(13)$ & & \\
\hline not at all sufficient & $11(9)$ & $2(9)$ & $13(8)$ & & \\
\hline unsure & $3(1)$ & $1(1)$ & $0(1)$ & & \\
\hline Duration of proposed financial incentive $(\mathrm{n}=112)$ & & & & 12.2 & 0.057 \\
\hline fully sufficient & $15(14)$ & $16(13)$ & $9(13)$ & & \\
\hline somewhat sufficient & $11(13)$ & $15(12)$ & $10(11)$ & & \\
\hline not at all sufficient & $11(10)$ & $3(10)$ & $15(9)$ & & \\
\hline unsure & $3(3)$ & $3(2)$ & $1(2)$ & & \\
\hline
\end{tabular}

Across study sites, marginally significant differences $(P=$ $0.064)$ in landowner perceptions of responsibility for clearing IAPs on private land were observed (Table 5). A greater percentage of Citrusdal landowners believed management of IAPs on private property should be primarily the government's responsibility $(29 \%, \mathrm{n}=34)$, compared to those located in Wilderness $(11 \%, \mathrm{n}=38)$ and Grabouw $(9 \%, \mathrm{n}=35)$.

Indicator value analysis demonstrated strong associations between two emergent themes and landowner study site (Tables 6 and 7). The theme "neighboring public lands have not been cleared" was associated with the Wilderness study site $(\mathrm{P}<0.01,46 \%, \mathrm{n}=41)$, the area with the greatest proportion of public lands. While the theme "riverside properties bear unfair costs" was associated with Citrusdal (P $<0.001,34 \%, \mathrm{n}=35$ ), the area where IAPs are largely concentrated along waterways.

\section{Policy tools}

Among all the stakeholders $(96 \%, \mathrm{n}=154)$, support for the use of extension services to motivate landowners to clear IAPs on their properties was overwhelming (Table 4). The majority of stakeholders $(86 \%, \mathrm{n}=154)$ supported the provision of financial assistance for landowners. However, there was differential support for the use of monetary incentives across stakeholder groups, with a larger percentage of WfW managers disagreeing with the use of such incentives $(44 \%, \mathrm{n}$ $=18)$, when compared to the landowners $(7 \%, \mathrm{n}=111)$ and conservation professionals $(12 \%, \mathrm{n}=25)$. Managers who disagreed with the use of financial incentives expressed a concern that emphasis on financial incentives alone would be insufficient. According to one manager, "No matter how much money is spent on the ground, it is all fruitless unless there is significant buy-in from the landowner."

The majority of all stakeholders $(71 \%, \mathrm{n}=155)$ believed clearing IAPs on private land should be required by law (Table 4). However, there were significant differences among stakeholder groups, and a greater percentage of landowners did not support $(30 \%, \mathrm{n}=112)$ the use of a legal mandate, when compared to either conservation professionals $(12 \%, \mathrm{n}$ $=25)$ or $\mathrm{WfW}$ managers $(6 \%, \mathrm{n}=18, P=0.05)$. These landowners were mainly concerned that a legal mandate would overstep their financial self-interest or property rights. 
Table 6. Emergent themes based on landowner responses to open-ended interview questions regarding (a) landowner and government responsibility for clearing invasive alien plants (IAPs); and (b) the quantity and duration of financial assistance proposed in WfW's approach to clearing IAPs on private land, Western Cape. Only themes showing a significant association with landowner study site or landowner responses to closed-ended questionnaire items are presented (see Table 7).

\begin{tabular}{lc}
\hline \hline Emergent Theme & $\begin{array}{l}\% \\
(\mathrm{n}=113)\end{array}$ \\
\hline
\end{tabular}

The spatial and temporal scale of IAP infestations transcends the scope of individual landowners and their property boundaries. Thus, government-led coordination, planning, and commitment will be required to clear IAPs.

Landowners can clear at a lower overall cost

No differences were found across the landowner study sites with respect to level of support for motivational, monetary or legal incentives (Table 5).

\section{Financial assistance}

Slightly more than a quarter of all the stakeholders combined believed the quantity (28\%) and duration (27\%) of WfW's proposed financial assistance would be fully sufficient to overcome landowners' financial barriers to clearing IAPs. The majority believed the proposed quantity $(43 \%, \mathrm{n}=150)$ and duration $(43 \%, \mathrm{n}=150)$ would be somewhat sufficient, and $21 \%$ believed the proposed financial assistance would wholly insufficient (Table 4).

Significant differences across stakeholder groups were observed, with a greater percentage of landowners who believed the quantity $(37 \%, \mathrm{n}=112)$ and duration $(37 \%, \mathrm{n}=$ 112) of the proposed assistance would be fully sufficient, than was the case among the conservation professionals $(0 \%$ and $4 \%$, respectively, $\mathrm{n}=25)$ and $\mathrm{WfW}$ managers $(8 \%$ and $0 \%$, respectively, $\mathrm{n}=13 ; \mathrm{p}<0.001$ and $\mathrm{p}<0.0001$ ).

Landowners from the three study sites also differed in their perceptions of WfW's proposed financial assistance (Table 5). A greater percentage of Grabouw landowners ( $49 \%, n=37)$ believed the quantity would be fully sufficient, compared to landowners in Wilderness $(33 \%, \mathrm{n}=40)$ and Citrusdal $(29 \%$, $\mathrm{n}=35)$. Conversely, a greater percentage $(P=0.057$; Table 4$)$ of landowners in both Grabouw $(43 \%, \mathrm{n}=37)$ and Wilderness $(38 \%, \mathrm{n}=40)$ believed the duration of the proposed financial assistance would be fully sufficient, compared to landowners in Citrusdal $(26 \%, \mathrm{n}=35)$. 
Table 7. Results from Dufrêne-Legendre Indicator Value Analysis of associations between landowner study site, landowner responses to closed-ended questionnaire items, and emergent themes regarding (a) landowner and government responsibility for clearing invasive alien plants (IAPs); or (b) the quantity and duration of financial assistance proposed in WfW's approach.

\begin{tabular}{|c|c|c|c|c|c|c|}
\hline & \multirow[t]{2}{*}{ Factor } & \multirow[t]{2}{*}{ Emergent theme(s) } & \multirow[t]{2}{*}{$\begin{array}{l}\text { IndVal. } \\
\text { (obs) } \dagger\end{array}$} & \multicolumn{3}{|c|}{$\begin{array}{l}\text { IndVal. from } \\
\text { randomization }\end{array}$} \\
\hline & & & & mean & SE & $p \ddagger$ \\
\hline \multirow[t]{8}{*}{ (a) } & Study Site & & & & & \\
\hline & - Wilderness & Neighboring public lands have not been cleared & 26 & 15.0 & 3.1 & $<0.01$ \\
\hline & - Citrusdal & Riverside properties bear unfair costs & 30 & 8.1 & 2.6 & $<0.001$ \\
\hline & Closed-ended response & & & & & \\
\hline & - Primarily/solely landowner & Landowners have a duty to steward property & 34 & 18.0 & 3.9 & $<0.01$ \\
\hline & & Landowners can clear at a lower overall cost & 22 & 8.6 & 3.2 & $<0.01$ \\
\hline & - Equal responsibility & Government coordination is needed & 23 & 15.0 & 4.0 & 0.06 \\
\hline & - Primarily/solely government & The state's historic role in IAP introduction and spread & 33 & 15.0 & 3.8 & $<0.01$ \\
\hline \multirow[t]{3}{*}{ (b) } & Study Site & & & & & \\
\hline & - Wilderness & Prefer to work more slowly & 18 & 12.0 & 3.0 & 0.05 \\
\hline & - Citrusdal & Ecological unpredictability & 31 & 19.0 & 3.2 & $<0.01$ \\
\hline
\end{tabular}

$\dagger$ Indicator values are presented as percentage of perfect association.

†Significance $(\mathrm{p}<0.05)$ was determined with Monte Carlo randomization. Only significant associations are presented.

Qualitative analysis of landowner interview transcriptions revealed six emergent themes associated with the financial structure of WfW's proposed approach (Table 6). Indicator value analysis detected associations between two emergent themes and the landowner study sites (Table 7). The theme "prefer to work more slowly" was associated with primarily residential landowners in Wilderness $(P=0.05 ; 34 \%, \mathrm{n}=41)$, while the theme "ecological unpredictability" was associated with landowners in Citrusdal $(P<0.01 ; 63 \%, \mathrm{n}=35)$, where landowners are primarily farmers with large property sizes and the greatest percentage of landowners have previous experience working with WFW to clear IAPs from their properties.

We did not find associations between emergent themes and landowners' categorical responses regarding the quantity and duration of financial assistance proposed in WfW's approach (Table 7).

\section{DISCUSSION}

Outcomes of ES schemes are strongly dependent on the degree to which institutional arrangements interact with the local ecological and socioeconomic context to influence the conservation behavior of landowners and other key stakeholders. Our results suggest that probing stakeholders directly is a valuable means of gaining insight into these contextual factors. We found strong associations between a few key factors and stakeholder perceptions toward the policy principles and financial structure of WfW's approach. Key factors included characteristics of the landowners, the landscapes in which they live, and the ESs they manage.

Several of the factors we identify as important may have broad relevance for the design of ES programs elsewhere. As such, these data contribute to the growing body of literature on the institutional design of an ES approach to conservation in working landscapes. We therefore outline the implications of our findings for the design of WfW's approach and frame this discussion within the broader scope of ESs.

\section{Government and landowner responsibility}

An overwhelming majority of stakeholders agreed that responsibility for IAP management on private land should be shared among landowners and the government. This finding bodes well for the development of collaborative partnerships to clear IAPs on private land in the Western Cape. Widespread recognition that responsibility for IAPs, and for associated ESs, lies in the hands of both public and private sectors reflects a general shift away from government command and control toward broader and more inclusive environmental governance, as documented elsewhere (Cocklin et al. 2007, Winter et al. 2007, Pasquini et al. 2010).

Nevertheless, there was variation in the level of responsibility landowners were willing to assume. Enhanced understanding of the values informing landowner perceptions of their responsibility in the stewardship of ESs can guide the design of institutions to better facilitate communication and understanding among stakeholders and, ultimately, better conserve ESs.

Landowners who believed they should take primary responsibility for clearing IAPs also tended to believe that they could do so at a lower overall cost. This belief seems to be based primarily on a perception that landowners hold knowledge of local resource dynamics that is superior to that of government. Landowners viewed themselves as best qualified for conducting the IAP clearing work and thus, landowner command of IAP management was justified as the most cost-effective and pragmatic alternative (Coase 1960, 
Siebert et al. 2006, German and Keeler 2010). These landowners also tended to believe that they have an ethical duty to steward their property, and thus to clear IAPs. This finding is consistent with previous studies that suggest landowners with a strong conservation ethic are more likely to be positively motivated to take responsibility for the conservation of ESs (Kabii and Horwitz 2006, Siebert et al. 2006).

In contrast, landowners who supported equal landowner and government responsibility tended to perceive a need for government coordination of IAP management across property boundaries. This finding echoes Goldman et al.'s (2007) conclusion that effective IAP management should occur across multiple landholdings and at a landscape scale. It also suggests that alien species are perceived as "weakest-link" public goods, i.e., the successful control of IAPs will be limited by the least effective provider (Perrings et al. 2002). In this case, the weakest link would be nonparticipant landowners.

Finally, landowners who expected the government to accept greater responsibility tended to refer to the state's historic role in the introduction and spread of IAPs (Carruthers et al. 2011). Since the state played a strong role in introducing IAPs, these landowners tend to believe the current government should accept a greater portion of the responsibility for removing the species once they become a problem. Landowners' responses suggest adherence to a "polluter pays" discourse of environmental governance, according to which the actor responsible for producing pollution (in this case the introduction of IAPs) should be held responsible for paying the damage rendered to the natural environment (Pigou 1932, Salzman 2005).

People's perceptions and landscape structures are in a reciprocal relationship (Nassauer 1995). We observed links between biophysical and land use attributes of the study sites and the perspectives of the landowners toward their own responsibility and that of the government. These findings emphasize the importance of both ecological and socioeconomic contexts in the design of institutions for ESs (Jack et al. 2008).

The perceptions of Wilderness landowners appeared to be influenced by a land use attribute, in that this site comprises a greater proportion of public land than the other two sites. Of the three sites, Wilderness contained the highest proportion of respondents who believed landowners should be primarily responsible for clearing IAPs. At the same time, Wilderness landowners tended to refer to the fact that neighboring public lands have not been cleared, and expressed concern that public lands would act as source populations for IAP (re)invasions onto their properties. Many of these landowners did not think the government should be responsible for IAP management on private land until adjoining public lands had been successfully cleared. Broader landscape-scale coordination across public and private landholdings was identified as an important criterion for effective acceptance of the approach among these landowners.

In contrast to Wilderness, Citrusdal contained the highest proportion of landowners who believed the government should be primarily responsible for clearing IAPs. This finding may be understood as a function of Citrusdal's arid climate, which results in the concentration of IAPs along rivers. This biophysical attribute appeared to influence landowner perceptions toward the division of responsibility for clearing IAPs. Riversides are critical areas for IAP management, both as conduits for IAP dispersal and as sources of the water benefits resulting from IAP clearing operations (Le Maitre et al. 1996, Le Maitre et al. 2000, Esler et al. 2008). As is the case with most ESs, water is a public resource, and landowners may not directly benefit from the increased water resources released by their own clearing efforts. It is therefore not surprising that Citrusdal landowners expressed concerns about riverside properties bearing unfair costs associated with IAP clearing, as these landowners bear a disproportionate cost, while resource benefits are shared more equally. Previous studies have noted concerns among landowners that they may be forced to bear disproportionate costs or incur losses from conservation initiatives that primarily benefit the public, thus creating or accentuating social and economic inequalities for certain landowners (Klapproth and Johnson 2001). The issue of who should pay, and how the needs and circumstances of different landowners can be addressed equitably, is a recurring theme among conservation initiatives on private land (Kabii and Horwitz 2006).

\section{Policy tools}

ES programs can call upon an array of mechanisms to encourage stakeholder engagement. Mechanisms include, for example, financial incentives, regulations (legal mandates), and motivational tools (extension services, education, and information) (Young et al. 1996, Botha 2001). Although there is generally a focus on financial incentives within the framework of ESs, whether these are more effective singly or as part of a policy mix, and how various instruments should be combined, are fundamental questions that remain to be answered (Engel et al. 2008).

The majority of stakeholders expressed support for the use of financial incentives, motivational tools, and regulations in WfW's Approach to Work on Private Land. This finding suggests that a mix of incentives and disincentives may be an effective approach to engage landowners in IAP clearing on their property. Policy analysis (Pagiola and Platais 2007) and economic theory (Landell-Mills and Porras 2002) in relation to ESs also suggest that the integration of financial payments with a broader array of policy approaches can improve the likelihood of achieving desired outcomes. 


\section{Financial incentives}

For ES payments to be an effective policy tool, incentives must be sufficient to offset private costs for engaging in conservation management. It is therefore important to note that the majority of stakeholders deemed the proposed financial structure to be only somewhat sufficient. Landowners were also more divided on this issue than was the case among the other stakeholder groups.

Landowners in Wilderness and Citrusdal were more likely than those in Grabouw to consider the proposed subsidy duration as wholly insufficient, but for different reasons. The largely residential landowners in Wilderness tended to prefer to work more slowly than was proposed, and expressed concerns that the rapid removal of IAPs could result in unintended negative consequences for native species, wildlife habitat, and/or their ability to utilize leftover IAP biomass. Use and adoption of IAPs in local livelihoods as natural resources (i.e., woodfuels, lumber, food) and as sources of wildlife habitat suggest a need to take into account the effects of IAP clearing on a broader suite of values and interests pertaining to ESs (Shackleton et al. 2007, Kull et al. 2011).

In contrast, Citrusdal landowners expressed concerns about a possible mismatch between the fixed structure of the proposed subsidy and the complex, dynamic nature of the ecological systems they aim to manage. This "problem of fit" between institutional arrangements and ecological dynamics is a welldocumented challenge in environmental governance (Folke et al. 2007). Landowners believed the financial subsidy should be adapted to accommodate ecological unpredictability in the form of unplanned fire events, new or emerging IAP species, or unanticipated variation in IAP response to control treatments. Within a fixed time frame, landowners feared that after the incentive period they could find their property "back to square one", without any additional IAP clearing assistance.

Landowners' previous experience in collaborating with WfW to clear IAP may also have been an important factor influencing perceptions of the proposed financial assistance. More than two-thirds of landowners in Citrusdal had worked with WfW before, while only $22 \%$ of landowners in Grabouw had such previous experience. At the same time, a much higher percentage of these Grabouw landowners (49\%) than their Citrusdal counterparts $(26 \%)$ considered the proposed financial assistance as fully sufficient. This finding suggests a potential obstacle to long-term IAP control if landowners' expectations are not met by management realities. WfW runs the risk of expending limited resources to clear IAPs in areas where landowners have not secured adequate resources to sustain the follow-up work after WfW's assistance period, and thus these areas may be more likely to return to premanagement conditions. Previous studies have shown that former participation in a similar scheme is a strong indicator of landowner willingness to participate in a conservation action (Morris and Potter 1995, Siebert et al. 2006). In contrast to previous studies, we found experienced landowners were more likely to possess a realistic portrait of the time and financial commitment required to do the work, and thus were more likely to decline engagement with the program, given the proposed financial incentive.

\section{CONCLUSION}

Enhanced understanding of the values informing landowner perceptions of their responsibility in the stewardship of ESs can guide the design of institutions to better facilitate communication and understanding among stakeholders and, ultimately, better conserve ESs. Our findings from the Western Cape suggest the following concepts should be considered in the design of institutions to clear IAPs and for the conservation of ESs on private lands:

- shared responsibility between landowners and government;

- a policy mix combining financial incentives with regulations and motivational tools;

- acknowledgement of the state's historical role in the introduction and spread of IAPs;

- integrated coordination of IAP management across public and private lands;

- incentives that target potentially greater costs, and ES benefits, resulting from IAP management in riparian compared to upland environments;

- consideration of a broader suite of ESs important to landowners (i.e., wildlife habitat, wood resources);

- design of more flexible financial assistance to respond to resource dynamics resulting from stochastic fire events, new and emerging IAP species, and/or unanticipated variation in treatment response; and

- effective communication to provide landowners with clear expectations regarding the level of IAP maintenance required over the long term.

An example of how these institutional design concepts could be applied in practice, would be to link WfW's financial assistance to IAP reductions levels, thus shifting away from a fixed time frame for financial assistance toward an incentive target defined by on the ground outcomes in reductions of IAP. This shift would allow for flexibility to match variation in environmental characteristics of individual properties, and thus address the "problem of fit" between fixed financial assistance and unpredictable ecological dynamics. A program that is orientated toward an IAP reduction target would reduce landowner concern that they could find their property "back to square one" without any additional IAP clearing assistance, and would thus support greater willingness of landowners to 
participate in IAP management on their property. We conclude that stakeholder analysis is a fundamental, although underrepresented, means of gaining insight into the opportunities and constraints that face ES conservation in working landscapes, and an important complement to biophysical and economic valuation methods of inquiry.

Responses to this article can be read online at: http://www.ecologyandsociety.org/issues/responses. $\mathrm{php} / 5259$

\section{Acknowledgments:}

Funding was provided by the National Science Foundation's Program in Integrative Graduate Education and Research Training (0333408) and the DST-NRF Centre of Excellence for Invasion Biology. The author's would like to thank the landowner, conservation professional, and WfW manager participants for sharing their time and considerable insights. We are grateful to the Working for Water Program, Western Cape, and particularly G. Preston, A. Khan, and D. Malan, for their invaluable suggestions and support. We thank $M$. Mouton, M. Peens, and A. Hough for assistance in the field.

\section{LITERATURE CITED}

Bakker, J. D. 2008. Increasing the utility of indicator species analysis. Journal of Applied Ecology 45:1829-1835.

Biernacki, P., and Waldorf, D. 1981. Snowball sampling: problems and techniques of chain referral sampling. Sociological Methods and Research 10:141-163.

Botha, M. 2001. Incentives for conservation on private land: options and opportunities. Summary Report 02/2001. Botanical Society of South Africa, Cape Conservation Unit, Cape Town, South Africa.

Carruthers, J., L. Robin, J.P. Hattingh, C.A. Kull, H. Rangan, and B.W. van Wilgen. 2011. A native at home and abroad: the history, politics, ethics and aesthetics of acacias. Diversity and Distributions 17:810-821. http://dx.doi.org/10.1111/ j.1472-4642.2011.00779.x

Coase, R. 1960. The problem of social cost. Journal of Law and Economics 3:1-44. http://dx.doi.org/10.1086/466560

Cocklin, C., N. Mautner, and J. Dibden. 2007. Public policy, private landholders: perspectives on policy mechanisms for sustainable land management. Journal of Environmental Management 85:986-998. http://dx.doi.org/10.1016/j. jenvman.2006.11.009

Cowling, R. M., B. Egoh, A. T. Knight, P. J. O'Farrell, B. Reyers, M. Rouget, D. J. Roux, A. Welz, and M. WilhelmRechman. 2008. An operational model for mainstreaming ecosystem services for implementation. Proceedings of the National Academy of Sciences 105:9483-9488. http://dx.doi. org/10.1073/pnas.0706559105

Cowling, R. M., and D. M. Richardson. 1995. Fynbos: South Africa's unique floral kingdom. Fernwood Press, Cape Town, South Africa.

Creswell, J. W. 2009. Research design: qualitative, quantitative, and mixed methods approaches. Sage, Thousand Oaks, California, USA.

Curtis, A., and A. Robertson. 2003. Understanding landholder management of river frontages: the Goulburn Broken. Ecological Management and Restoration 4:45-54. http://dx. doi.org/10.1046/j.1442-8903.2003.t01-1-00137.x

Daily, G., Polasky, S., Goldstein, J., Kareiva, P.M., Mooney, H.A., Pejchar, L., Ricketts, T.H., Salzman, J., and R. Shallenberger. 2009. Ecosystem services in decision making: time to deliver. Frontiers in Ecology and the Environment 7:21-28. http://dx.doi.org/10.1890/080025

Department of Water Affairs and Forestry (DWAF). 2007. WfW information brochure. DWAF, Pretoria, South Africa. [online] URL: http://www.dwaf.gov.za/wfw/Docs/Books/ brochure07.pdf

Dufrêne, M., and P. Legendre. 1997. Species assemblages and indicator species: the need for a flexible asymmetrical approach. Ecological Monographs 67:345-366.

Engel, S., S. Pagiola, S., and S. Wunder. 2008. Designing payments for environmental services in theory and practice: an overview of the issues. Ecological Economics 65 (4):663-674. http://dx.doi.org/10.1016/j.ecolecon.2008.03.011

Esler, K. J., P. Holmes, D. M. Richardson, and E. T. F. Witkowski. 2008. Riparian vegetation management in landscapes invaded by alien plants: insights from South Africa. South African Journal of Botany 74:397-400.

Folke, C., L. Pritchard, F. Berkes, J. Colding, and U. Svedin. 2007. The problem of fit between ecosystems and institutions: ten years later. Ecology and Society 12:30. [online] URL: http://www.ecologyandsociety.org/vol12/iss 1/art30/

German, L. A., and A. Keeler. 2010. Hybrid institutions: applications of common property theory beyond discrete property regimes. International Journal of the Commons 4:571-596.

Goldman, R. L, B. H. Thompson, and G.H. Daily. 2007. Institutional incentives for managing the landscape: inducing cooperation for the production of ecosystem services. Ecological Economics 64:333-343. http://dx.doi.org/10.1016/ j.ecolecon.2007.01.012

Grimble, R., and K. Wellard. 1997. Stakeholder methodologies in natural resource management: a review of 
principles, contexts, experiences and opportunities. Agricultural Systems 55:173-193. http://dx.doi.org/10.1016/ S0308-521X(97)00006-1

Hanna, S. S., C. Folke, and K. G. Maler, editors. 1997. Rights to nature: ecological, economic, cultural and political principles of institutions for the environment. Island Press. Washington, D. C., USA.

Holmes, P. M., K. J. Esler, D. M. Richardson, and E. T. F. Witkowski. 2008. Guidelines for improved management of riparian zones invaded by alien plants in South Africa. South African Journal of Botany 74:538-552. http://dx.doi. org/10.1016/j.sajb.2008.01.182

Jack, K. B, C. Kousky, and K. R. E. Sims. 2008. Designing payments for ecosystem services: lessons from previous experience with incentive-based mechanisms. Proceedings of the National Academy of Sciences 105:9465-9470. http://dx. doi.org/10.1073/pnas.0705503104

Kabii, T., and P. Horwitz. 2006. A review of landholder motivations and determinants for participation in conservation covenanting programmes. Environmental Conservation 33:11-20. http://dx.doi.org/10.1017/S0376892906002761

Klapproth, J. C., and J. E. Johnson. 2001. Understanding the science behind riparian forest buffers: benefits to communities and landowners. Virginia Cooperative Extension, Petersburg, Virginia**, USA.

Kull, C. A., C. M. Shackleton, P. Cunningham, C. Ducatillon, J. M. Dufour Dror, K. J. Esler, J. B. Friday, A. C. Gouveia, A. R. Griffin, E. M. Marchante, S. J. Midgley, A. Pauchard, H. Rangan, D. M. Richardson, T. Rinaudo, J. Tassin, L. S. Urgenson, G. P. von Maltitz, R. D. Zenni, and M. J. Zylstra. 2011. Adoption, use, and perception of Australian acacias around the world. Diversity and Distributions 17:822-836.

Landell-Mills, N., and I. T. Porras. 2002. Silver bullet or fools' gold? A global review of markets for forest environmental services and their impacts on the poor. Instruments for Sustainable Private Sector Forestry Series. International Institute for Environment and Development, London, U.K.

Le Maitre, D. C., B. W. Van Wilgen, R. A. Chapman, and D. H. McKelly. 1996. Invasive plants and water resources in the Western Cape Province, South Africa: modeling the consequences of a lack of management. Journal of Applied Ecology 33:161-172. http://dx.doi.org/10.2307/2405025

Le Maitre, D. C., D. B. Versveld, and R. A. Chapman. 2000. The impact of invading alien plants on surface water resources in South Africa: a preliminary assessment. Water SA 26:397408.

Marais, C., and A. M. Wannenburgh. 2008. Restoration of water resources (natural capital) through the clearing of invasive alien plants from riparian areas in South Africa - costs and water benefits. South African Journal of Botany 74:526-537. http://dx.doi.org/10.1016/j.sajb.2008.01.175

Menzel, S., and J. Teng. 2010. Ecosystem services as a stakeholder-driven concept for conservation science. Conservation Biology 24:907-909.

Millennium Ecosystem Assessment. 2005. Millennium ecosystem assessment. Ecosystems and human well-being: synthesis. Island Press, Washington, D. C., USA. [online] URL: http://www.unep.org/maweb/en/synthesis.aspx

Moon, K., and C. Cocklin. 2011. A landholder-based approach to the design of private-land conservation programs. Conservation Biology 25:493-503. http://dx.doi.org/10.1111/ j.1523-1739.2010.01639.x

Morris, C., and C. Potter. 1995. Recruiting the new conservationists: farmers' adoption of agri-environmental schemes in the U.K. Journal of Rural Studies 1:51-63. http:// dx.doi.org/10.1016/0743-0167(94)00037-A

Nassauer, J. I. 1995. Messy ecosystems, orderly frames. Landscape Journal 14:161-170.

North, D. 1990. Institutions, institutional change and economic performance. Cambridge University Press. New York, New York, USA. http://dx.doi.org/10.1017/ CBO9780511808678

Orkin, F. 1998. Living in the Western Cape: selected findings of the 1995 October household survey. Central Statistics, Pretoria, South Africa.

Ostrom E. 1990. Governing the commons: the evolution of institutions for collective action. Cambridge University Press, Cambridge, UK. http://dx.doi.org/10.1017/CBO9780511807763

Pagiola, S., and G. Platais. 2007. Payments for environmental services: from theory to practice. World Bank, Washington, D. C., USA.

Pasquini, L., R. M. Cowling, C. Twyman, and J. Wainwright. 2010. Devising appropriate policies and instruments in support of private conservation areas: lessons learned from the Klein Karoo, South Africa. Conservation Biology 24:470-478. http://dx.doi.org/10.1111/j.1523-1739.2009.01344.x

Perrings, C., M. Williamson, E. B. Barbier, D. Delfino, S. Dalmazzone, J. Shogren, P. Simmons, and A. Watkinson. 2002. Biological invasion risks and the public good: an economic perspective. Conservation Ecology 6(1):1. [online] URL:http://www.consecol.org/vol6/iss1/art1/

Pigou, A. 1932. The economics of welfare, 4th edition. Macmillan and Company, London, UK.

Prell, C., M. Reed, L. Racin, and K. Hubacek. 2010. Competing structure, competing views: the role of formal and informal social structures in shaping stakeholder perceptions. 
Ecology and Society 15:34. [online] URL: http://www. ecologyandsociety.org/vol15/iss4/art34/

Pretorius, M. R., K. J. Esler, P. M. Holmes, and N. Prins. 2008. The effectiveness of active restoration following alien clearance in fynbos riparian zones and resilience of treatments to fire. South African Journal of Botany 74:517-525. http://dx. doi.org/10.1016/j.sajb.2008.01.180

Rebelo, A. G., and W. R. Siegfried. 1992. Where should nature reserves be located in the Cape Floristic Region, South Africa? Models for the spatial configuration of a reserve network aimed at maximizing the protection of floral diversity. Conservation Biology 6:243-252. http://dx.doi.org/10.1046/ j.1523-1739.1992.620243.x

Reed, M. S. 2008. Stakeholder participation for environmental management: a literature review. Biological Conservation 141:2417-2431. http://dx.doi.org/10.1016/j.biocon.2008.07.014

Roura-Pascual, N., D. M. Richardson, R. M. Krug, A. Brown, R. A. Chapman, G. G. Forsyth, D. C. Le Maitre, M. P. Robertson, L. Stafford, B. W. Van Wilgen, A. Wannenburgh, and N. Wessels. 2009. Ecology and management of alien plant invasions in South African fynbos: accommodating key complexities in objective decision making. Biological Conservation 142:1595-1604. http://dx.doi.org/10.1016/j. biocon.2009.02.029

Salzman, J. E. 2005. Creating markets for ecosystem services: notes from the field. New York University Law Review 80:870-961.

Schirmer, J., S. Dovers, and H. Clayton. 2012. Informing conservation policy design through an examination of landholder preferences: a case study of scattered tree conservation in Australia. Biological Conservation 153:51-63. http://dx.doi.org/10.1016/j.biocon.2012.04.014

Shackleton, C. M., D. McGarry, S. Fourie, J. Gambiza, S. E. Shackleton, and C. Fabricius. 2007. Assessing the effects of invasive alien species on rural livelihoods: case examples and a framework from South Africa. Human Ecology 35:113-127.

Siebert, R., M. Toogood, and A. Knierim. 2006. Factors affecting European farmers' participation in biodiversity policies. Sociologia Ruralis 46:318-340. http://dx.doi. org/10.1111/j.1467-9523.2006.00420.x

Tashakkori, A., and C. Teddlie. 2003. Sage handbook of mixed methods in social and behavioral research. Sage, Thousand Oaks, California, USA.

Turner, R. K., and G. C. Daily. 2008. The ecosystem services framework and natural capital conservation. Environmental and Resource Economics 39:25-35.

Turpie, J. K., C. Marais, and J. N. Blignaut. 2008. The Working for Water Programme: evolution of a payments for ecosystem services mechanism that addresses both poverty and ecosystem service delivery in South Africa. Ecological Economics 65:788-798. http://dx.doi.org/10.1016/j. ecolecon.2007.12.024

Van Wilgen, B. W. 2009. The evolution of fire and invasive alien plant management practices in fynbos. South African Journal of Science 106:335-342.

Van Wilgen, B. W., R. M. Cowling, and D. C. Le Maitre. 1998. Ecosystem services, efficiency, sustainability and equity: South Africa's Working for Water Programme. Trends in Ecology and Evolution 13:378.

Van Wyk, D. 1987. Some effects of afforestation on streamflow in the Western Cape Province, South Africa. Water SA 13:31-36.

Wandel, J., and J. Smithers. 2000. Factors affecting the adoption of conservation tillage on clay soils in Southwestern Ontario, Canada. American Journal of Alternative Agriculture 15:181-188. http://dx.doi.org/10.1017/S0889189300008754

Winter, S., H. Prozesky, and K. J. Esler. 2007. A case study of landholder attitudes and behaviour toward the conservation of renosterveld, a critically endangered vegetation type in Cape Floral Kingdom, South Africa. Environmental Management 40:46-61. http://dx.doi.org/10.1007/s00267-006-0086-0

Witt, H. 2003. The emergence of privately owned industrial tree plantations. Pages 90-111 in S. Dovers, and R. Edgecombe, editors. South Africa's environmental history: cases and comparisons. David Phillip, Cape Town, South Africa.

Wondolleck, J., and S. L. Yaffee. 2000. Making collaboration work: lessons from innovation in natural resource management. Island Press, Washington, D. C., USA.

Woodworth, P. 2006. Working for Water in South Africa: saving the world on a single budget? World Policy Journal Summer:31-43.

Young, M. D., N. Gunningham, J. Elix, J. Lambert, B. Howard, P. Grabosky, and E. McCrone. 1996. Reimbursing the future: an evaluation of motivational, voluntary, price-based, property-right, and regulatory incentives for the conservation of biological diversity. Biodiversity series, paper 9. Department of the Environment, Sport and Territories, Canberra, Australia. 